原著

\title{
麻痺性嚥下障害に対する嚥下反射促通手技の臨床応用
}

\author{
小島 義次 植村 研一
}

\begin{abstract}
要 約：舆下反射促通手技を臨床応用したところ, 麻痺性嚥下障害の 6 名のうち 5 名に促通 刺激による臙下所要時間の短縮が認められた。この促通手技は,随意的な嚥下が困難であった り,著しく遅れるような場合に曣下運動を反復して誘発することができ, 嚥下に関わる筋群の可 動性を保持・強化するのに有効な手段である.
\end{abstract}

索引用語：麻痺性嚥下障害, 嚥下訓練, 嚥下反射促通手技

\section{Application of a Technique to Facilitate Swallowing by Dysphagic Patients}

\author{
Yoshiji Kojima, Kenichi Uemura
}

\begin{abstract}
We applied a technique to facilitate the swallowing reflex in six dysphagic patients. Five patients showed improved swallowing time. As this technique was able to evoke repeated swallowing movements in dysphagic patients, it is seen to be useful for maintaining and strengthening the mobility of musculatures for swallowing.
\end{abstract}

Key words : dysphagia training method, facilitating technique for swallowing

\section{はじめに}

麻痺性嚥下障害の訓練に際して, 患者自身の努力で は嚥下反射が生じにくいときや生じても著しく遅れる 場合, 外的に噁下を誘発する手だてが好都合である。こ れまでに, 口腔領域の刺激によって嚥下が引き起こさ

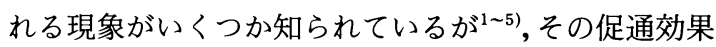
や応用手順の検討はなされていない.ここでは, 甲状軟 骨部から下頷下面の摩擦刺激を用いて勳下反射を促通 する技法 ${ }^{5)}$ の臨床応用について述べたい。

\section{圜下促通手技の臨床応用}

用いた曣下の誘発法は, 患者に飲み込む努力を求め
ながら患者の甲状軟骨部から下澦下面にかけて指で上 下に摩擦刺激を繰り返すものである(図 1 ).頭位は,後 屈しがちであるが,むしろ飲み込む努力にあわせて顎 を軽く引くように前屈させて,これに摩擦刺激してい る手で抵抗を加えるようにすると嚥下が誘発されやす い.

症例は,脳血管障害による麻痺性嚥下障害があり,経 口摂取に主治医の賛意がある者とした.以下,症例を提 示する.なお症例 1 は, 学会報告例である ${ }^{5)}$ が,詳細を 示す余裕がなかったので再提示したい.

症例 $1: 52$ 歳の男性. 7 年前から呂律が回わりにく かった.再発して発話不能と嚥下困難をきたした.頭部 CTでは, 左被殼と右尾状核に複数の小低吸収値域が 
あり,脳萎縮も認められた。 4 力月後の初診時, 会話明 瞭度はV $\mathrm{V}$ (全くわからない)であった。たんのからんだ 粗䊁性の声であり, 発声時の軟口蓋の挙上はみられな い./a/の発声持続は最大 10 秒であった. 流涎が頻回 にみられるが, 唾を飲み込むよう指示するとやや時間 を要するものの独力で飲み込むことができた.

本症例に嬩下誘発効果の検討を行った.できるだけ 速く飲み込むように指示して,ストローで定量( 1 cc)の水滴を舌の中央にたらし, 下滴から甲状軟骨が動 いて曣下が確認できるまでの時間を計測した。促通を しない自力での嚥下を先に行い, 間に 30 分の構音訓練 をはさんで, 促通刺激を加えた䜩下を行う条件と, 逆に 促通嚥下を先に行い, 30 分の構音訓練の後に自力によ る䜩下を行う条件とを 5 回ずつ, 両条件を交互に日を かえておのおの 35 回まで行った.

結果を表 1 に示した.所要時間の平均は, 自力嚥下を 先に行う試行がどの促通嚥下の試行よりも有意に長か つた(促通が後続する条件で $\mathrm{t}=4.997, \mathrm{p}<0.001$ : 促 通が先行する条件で $\mathrm{t}=2,980, \mathrm{p}<0.01$. 関連のある測 定值についての $\mathrm{t}$ 検定による. 以下, 同様).一方で, 促

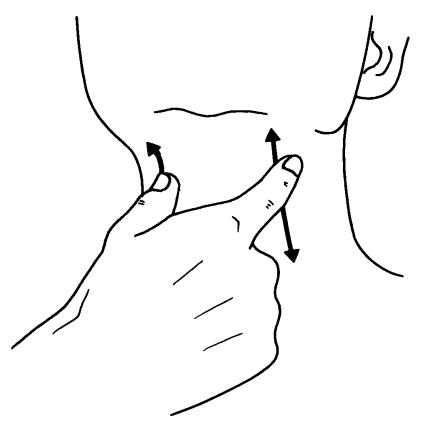

図 1 嬹下反射促通手技における刺激部位
通が先行した後で行う自力嬩下試行で平均值が最も低 くなっており, 先だつ促通試行の効果の持続ならびに 間に行われた構音訓練の影響を示すものと考えられ た.また, 平均值士 3 秒の範囲で曣下が可能であった試 行数の割合では, 先行または後続の条件にかかわらず, 自力曣下では $30 \%$ 台であるのに対して促通嚥下では $50 \%$ 台となっており, 促通を加えた場合に嚥下がその 所要時間の平均值付近で生じる割合が高くなってい る.この点も促通効果を示す結果と考えられた.

症例 $2: 66$ 歳の男性. 前交通動脈動脈瘤破裂による クモ膜下出血. 某病院で clipping 術が行われた.術後, 水頭症を認めたために V-P shunt 術を施行したが, 骮有 膜炎をきたして意識障害が続いた. 症状が改善せず当 院に転院となった。頭部 CT にて左前頭葉と右基底核 部に低吸収値域を認めた。その後, 意識が改善し歩行も 可能となったが, 臙下困難が続いたので発症 10 力月目 に言語室受診となった.

気管切開がなされており,カニュレに栓をして/a/ の最大発声持続が 7 秒であった.気息性で声量に乏し く, 会話明瞭度はII (ときどきわからない言葉がある) であった.きざみ食に七部がゆを経口摂取していたが, 誤飲によるむせがひどく,ときどき吸引が必要であっ た。喉頭の耳鼻咽喉科視診で梨状陥凹にだ液の貯留と 気管への迷入が観察されている.

水滴の噯下は, 12 から 32 秒で可能であったが, 数回 の下滴一鰂下を繰り返すとむせてしまった。しだいに 梨状陷凹部に貯留が増してこれがむせの原因になって いると考えられた.嚥下の後に数回のせき払いないし は発声を行わせ, 直後に促通手技により,さらに $1 \sim 2$ 回の臙下反射を誘発して, 曣下を確認した後に次の下 滴を行うようにすると著しいむせの減少が得られた. 促通刺激を加えた場合のほうが促通がない場合より も,それに続く嬩下が確実に得られた。そこで,この手 順による水滴の嶼下訓練を積極的に行った。

表 1 促通刺激がある場合とない場合の水滴嚥下所要時間の 比較（症例 1 )

\begin{tabular}{|c|c|c|}
\hline $\begin{array}{l}\text { 促通がない自力噮下 } \\
\text { が先行した場合 }\end{array}$ & 平均（範囲） & $\begin{array}{l}\text { 平均 } \pm 3 \text { sec. で } \\
\text { 臙下可能の試行数 }\end{array}$ \\
\hline 自力嶼下 & $23.8(13 \sim 50)$ sec. & $11(31.4 \%)$ \\
\hline 促通曣下 & $15.0(7 \sim 37)$ sec. & $18(51.4 \%)$ \\
\hline $\begin{array}{l}\text { 促通䜩下が先行 } \\
\text { した場合 }\end{array}$ & 平均（範囲） & $\begin{array}{l}\text { 平均 } \pm 3 \text { sec. で } \\
\text { 曣下可能の試行数 }\end{array}$ \\
\hline 促通睰下 & $18.0(6 \sim 35) \mathrm{sec}$ & $20(57.1 \%)$ \\
\hline 自力魦下 & $14.9(5 \sim 32) \mathrm{sec}$. & $13(37.1 \%)$ \\
\hline
\end{tabular}


食事でも同様に,ひと口嚥下するたびに数回のせき 払いないしは発声を行わせ,促通を加えながらさらに $1 〜 2$ 回嚥下させた後に, 次を摄取するように励行さ せることでむせが減少した. 1 力月後には, 吸引の必要 もなくなったので気管切開部を癒着閉鎖させるため力 ニュレが抜去された.すると切開部から呼気がもれる ため十分なせきばらいができなくなり，むせが増した。 そこで切開部の縫合閉鎖を行って,むせが隇じた。切開 部が閉鎖されたこともあり, 発声持続時間は 15 秒に延 長し声量も増加した. 10 力月後, 食事中に多小せきこ むことがあるということであったが,家業を少し再開 するまでに回復した。

症例 $3: 63$ 歳の男性. 8 年前の脳血栓で左不全片麻 痺となる。再発して構音障害と嚥下障害をきたした。頭 部 CT では, 脳萎縮, 右内包部と両側前頭葉に多発性に 小低吸収值域がみられ, 橋部右側にも低吸収值域を認 めた. 4 力月後に当科を受診した.

初診時の会話明瞭度はIV（ときどきわかる言葉があ る)である.たんのからんだ粗䊁性の声であり, 発声時 の軟口蓋の挙上はみられない./a/の最大発声持続は 5 秒であった。流涎が頻回にみられ，唾を飲み込むよう 指示しても随意的には困難であり, 上向いて噮下が起 こるのを待つようすであった.食事は常食を経口摄取 できたが,汁物でむせるため葛湯様にトロミをつけて 食していた。

$1 \mathrm{cc}$ の水滴嚥下は, 偶発的に生じることがあった が,多くは努力にもかかわらず反射が起こらず,検者に 甲状軟骨の動きが触知されないまま飲み込んだと主張 した.そして,さらに下滴を続けるとむせた。これに対 して促通刺激を加える場合は, 水滴喂下を 30 回行っ て,所要時間の平均は 13.1 (範囲 2 29) 秒であった。

そこで促通刺激を利用した臙下運動の訓練を行っ た.飲み込む努力を求めながらストローで下滴後ただ ちに促通刺激を加えた。同時に患者の人差指を喉仏に あてさせて嚥下時の甲状軟骨の動きを触知させた。そ の動きがあるまで讌下努力を続けることの重要さを嚥 下の仕組と合わせて説明した。また，曣下反射が生じた ことを確認したら,数回のせき払いないし発声を行わ せた。まもなく,促通による睑下を繰り返し行った直後 には自力でも水滴を飲み込むことができるようになっ てきた。また,曣下が起こりにくいときには自ら頸部に 手をあてて刺激して飲み込むようすもみられた。

訓練開始後 1 力月目では, 促通による嚥下を先行さ せなくとも自力嚥下が可能となり, 30 回の嚥下を行っ て,その所要時間が平均 23.8 (範囲 4〜 72) 秒となった。 さらに, 3 力月目の同所要時間は,平均 9.4 (範囲 2
～30) 秒と有意に短縮した $(\mathrm{t}=4.90, \mathrm{p}<0.001)$.この結 果, 唾がたまったら適宜に飲み込むように指示してい れば,流涎を防ぐことができた.しかし，注意を促して いないと,下を向いたり,口を開いたりする拍子に流涎 がみられた。たんのからんだ声の質が減じて/a/の最 大発声持続は 12 秒に延長した。

症例 $4: 64$ 歳の男性.糖尿病で投薬を受けていた。 1 年前に右上肢の軽い麻痺があった。このたびの再発 で発話の困難と藇下障害をきたし，また左手足の動き がにぶくつまずきやすくなった.頭部 CT では,前頭葉 の萎縮と脳室の拡大, および内包から視床にかけて複 数の低吸収值域を認め,多発性脳梗塞と診断された. 1 カ月後に言語室を受診した。

$/ \mathrm{a} /$ の発声持続時間は,最大が 10 秒であった。たん のからんだ粗䊁性の強い声で, 開鼻性も認められた。会 話明瞭度はIII (内容を知っていればわかる)であった。 全粥食を摂っており,颃茶やみそ汁はむせるので避け ている.だえきを飲み込むように指示すると 8 秒で飲 み込むが,つづけてもう一度飲み込むように求めると 3 分待っても嚥下が生じなかった. $1 \mathrm{cc}$ の水滴の嚥下 では甲状軟骨の動きが触知されず, 飲み込んだと主張 した.直後に発声させるとたんのからんだ声が顕著と なった。促通刺激を伴う場合は, 30 回行って鯃下所要 時間の平均が 12.5 (範囲 5 〜5) 秒であったが, 25 回目 に 1 度せき込んだ。

促通による水滴の䁩下訓練を実施した。飲み込みに 伴う甲状軟骨の動きを触知させ，その動きがあるまで 曣下努力をさせた。曣下運動が触知されたらだたちに せき払いを数回行わせた。以上の手順で促通を加えた 臙下を訓練したのち, 水滴の自力での嚥下を行った.下 滴後, 10 秒程度で曣下運動が生じないときは,せき払 いを数回行わせた後に,飲み込む努力をさせながら促 通刺激を加えて曣下させた. 2 力月後には, 自力での曣 下が可能となった. 30 回の䱏下所要時間の平均が 23.1 (範囲 7 ～52)秒であった。この頃より，お茶など も,どうかするとむせるが飲めるようになったという ことであった。たんのからんだ声の質がとれて, 発声持 続時間も 18 秒と延長した。

症例 5：33 歳の女性.全身エリマトーデス合併妊娠 後の全身浮腫にて加療中であった。突然に眼振, 左角膜 反射低下, Horner 徴候, 右半身痛覚消失, 口蓋垂右方 偏位, 構音障害ならびに高度の嚥下障害をきたした。 MRI にて延髄上外側部に $3 \mathrm{~mm}$ 程度の出血性梗塞を 示唆する病変が認められ, Wallenberg 症候群と診断 された。発症から 6 日目に㯖下指導の目的で言語室を 紹介された。 
全く飲み込めなかったが, 受診前日の昼から流動食, ビスケットが食べられるようになってきたとのことで あった./a/の発声持続時間は, 開鼻声を伴い, 最大が 10 秒であった。会話明瞭度はI（全部わかる)である が,ことに文章の音読で開鼻声が目立った.また, 音節 /pa/などの速い反復で鼻雑音が聴取された.

水滴嚥下では頸上部の摩擦刺激を反復しても促通効 果は得られにくく,むしろ, 噮下努力に合わせて甲状軟 骨から舌骨部の両側を指で支えてゆっくり押し上げる ようにすると臙下が誘発された。この方法で下滴によ る曣下運動の訓練を行った。

当初, 食事中にむせがみられ, 食後にせき払いをする と出てくるたんに味がすると訴えた。また,肺野雑音が 聴取された. 就寝中せき込みがあった.ひと口摄取する ごとにせき払いと上記の促通によりさらに $1 \sim 2$ 回の 嚥下を行った後に次の攝取をさせ，また食後にも十分 なせき払いを繰り返すことを励行させた. 1 力月後に は,ゆっくり食事をすればむせることはなくなり,夜間 のせき込みもなくなった。食後に肺野雑音が聴取され ることもほとんどなくなった.発声持続は, 15 秒可能 となったが, 開鼻声が残った。

症例 $6: 67$ 歳の男性. 10 年前に右上肢の感覚鈍麻が あった. 3 力月前,さらに右上下肢の不全麻痺をきた し, 呂律がまわりにくかったが, 気にならない程度に改 善した。しかし,このたびは右上下肢の不全麻痺の増強 に加えて高度の構音障害を呈した.多発性脳梗塞との 診断で某病院にて保存的治療を受けた。構音障害が改 善しないため言語訓練を希望して発症 1 力月半に当言 語室を受診した。

会話明瞭度はIV(ときどき分かる言葉がある)であっ た./a/の発声持続時間は最大で 11 秒可能であった が, たんのからんだ努力性の強い声で, 開鼻性も認め た.右口角から流涎があり, 唾液を飲み込むように指示 しても困難であった.また, 水滴の曣下では, 甲状軟骨 部の動きがないままに飲み込んだと主張することが多 く, 促通刺激を加えても嚥下運動は誘発されなかった。 したがって, 本症例は促通刺激による臙下訓練の対象 とはせず,通常の構音訓練のみを行った.訓練 2 カ月の 時点では, 唾液を随意的に飲み込むことは困難であり, 声の質に変化なく発声持続時間も 8 秒から 12 秒にと どまった。

\section{考察}

ここで用いた方法は, 随意的な嚥下が困難な局面に あたって,外的刺激を用いて嚥下運動を誘発するもの である.1例を除いて全例に曣下所要時間の改善が認
められた.また, 與下を誘発したときに甲状軟骨部の動 きを触知させてその動きを目標に嶼下努力を促すこと ができた.また,飲み込んだ後の残留をせき払いと同時 に促通を加えながら嚥下除去して, 次の嚥下にそなえ させることも誤嚥を減らすうえで効果があった。下滴 䜩下訓練の継続により曣下の改善もみられ, 本手技は 嬹下反射の誘発を反復することによって嬩下運動に関 わる筋群の可動性を保持・強化するうえで有効な手段 であると思われた.あわせて, 発声持続時間の延長と声 の質にも改善がみられた。この点は, 構音も拱食も大部 分共通の器官によっており, 一方の改善が他方の改善 につながったと考えられる ${ }^{6)}$.しかし, 構音との関連に おいて嬩下の問題を見逃し得ない理由はこれに留まら ないのではないか。十分な飲下しができないことによ つて食べかすやだ液が貯留してこれが不随意的に発声 発語器官の筋緊張を高めて構音を妨げると考えられる からである7).少量の食べかすやだ液を飲み込む習慣 づけも声の改善に役だったものと考えられた。こうし た構音訓練における曣下障害の問題は,これまでとり あげては論じられていないが今後の研究がまたれる点 であろう。

もちろん提示症例の改善が,すべて本手技の効果に よるものであるとすることはできない.第一に発症ま もない症例では自然回復があることである.第二は, 本 手技が構音訓練を含んだ他のアプローチとの併用で行 われたものである点である.しかし,なおもこの方法を 訓練の一部に組み入れて利用すべきであると主張する のには, 本手技が利用できなかった症例 6 では, 他症例 と同程度の短期間では嚥下・発声ともに改善がなかっ たことを傍証とすることができるかもしれない.嚥下 障害は急を要する問題であり, 総合的な取り組みが必 要な複雑なプロセスの障害でもある ${ }^{4,8}$. 特定の手続き を取り出してその効果を検討するということは, 今回 のデータからは厳密には困難であるように思われた。

さらに疑問もある.症例 6 のように嚥下反射が誘発 されない症例があり,誘発される症例との違いはこの たびの検討では明らかでない.また, 症例 5 では摩擦刺 激を反復するよりも, 甲状軟骨から舌骨部を押しあげ るようにするほうが有効であった。この点は, 先に報告 した Wallenberg 症候群の症例の場合 ${ }^{5)}$ と同様の所見 であった.このような症例による誘発効果の違いにつ いては, 嶼下反射が誘発される神経生理学的な機序と あわせて今後さらに検討したい.

また,訓練に際して誤嚥による危険の問題も留意し なければならない.ことに,むせのない誤嚥を示す症例 のあることが知られているので注意を要する ${ }^{9,10)}$.一方 


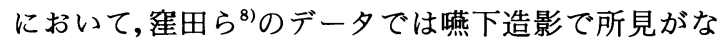
くてしかも食事中にむせることを訴える症例があり, 食素材の違いによって嚥下動態も一様ではないものと 考えられる.日常臨床では患者の体調, ことに体温の変 化や胸部聴診所見に十分な注意を払いながら訓練を進 める必要があろう ${ }^{11)}$.

\section{文献}

1）小島義次：仮性球麻痺患者にみられた強制笑いに ついて一発話運動との関連を中心に一. 恥覚言語 障害, 11 : 101-106, 1982.

2）小島義次, 窪田俊夫：脳血管障害患者にみられる 「口角と声の現象」について一構音ならびに嚥下訓 練における意義についての考察一. 音声言語医学, $24: 128-134,1983$.

3) Gaffney, T. W., Campbell, R. P. : Feeding techniques for dysphagic patients. Am. J. Nursing, 74 : 2194-2195, 1974.

4) Steefel, J. S. : Dysphagia rehabilitation for neurologically impaired adults. Charles C. Thomas, 1981. (柴田貞雄監訳：臙下障害のリハ ビリテーション, p. 48-50, 協同医書出版)

5）小島義次, 河原めぐみ：重度麻痺性構音障害患者 の発声発語器官の運動態様一その促通と抑制一.
音声言語医学, $21: 40-41,1980$.

6）柴田貞雄：麻痺性構音障害. 笹沼澄子編：リハビ リテーション医学全書 11, 言語障害. 医歯薬出版, pp. 155-244, 1975.

7）小島義次：運動性構音障害患者の発声発語器官に みられる運動障害の諸相. 聴能言語研究, $7:$ 101103, 1990.

8）窪田俊夫,三島博信,花田 実,他：脳血管障害に おける麻盘性嬿下障害一スクリーニングテストと その臨床応用について一. 総合リハ, $10 ： 271-276$, 1982.

9) Linden, P., Siebens, A. A. : Dysphagia : Predicting laryngeal penetration. Arch. Phys. Med. Rehabil., 64 : 281-284, 1983.

10）才藤栄一, 木村彰男, 矢守茂, 他：曣下障害のリハ ビリテーションにおける videofluorographyの 応用.り八医学, $23: 121-124,1986$.

11）矢守 茂, 永田雅章, 野町昭三郎, 他：臙下障害の リハビリテーション.総合リハ, $14: 45-48,1986$.

\section{別刷請求先： $\overline{\mathbf{T}} 431-31$ 静岡県浜松市半田町 3600 番地 浜松医科大学脑神経外科 小島義次}

